Forum Kritika: Performance and Domination

\title{
PERFORMING THE PEACE PROCESS AND PERFORMING THE PAST IN THE IRISH REPUBLICAN COMMEMORATION
}

\author{
Paddy Hoey \\ Edge Hill University \\ hoeyp@edgehill.ac.uk
}

\begin{abstract}
In the years since the signing of the 1998 Good Friday Peace Agreement in Northern Ireland, there has been a structural realignment of the Irish republican activist milieu. The agreement delivered the end of armed struggle for the largest republican militant group, the Provisional IRA, and provided the opportunity for the electoral growth of its formerly subordinate political wing, Sinn Féin. The latter has become the dominant gatekeeper of republican identity, defining ideologically important performative rituals, like commemorations. During the period of the Peace Process, these rituals self-consciously eschewed armed and uniformed displays of military force that were central to the propaganda war of the Troubles, such as those of the Hunger Strikes in 1981. New performative rituals of commemoration symbolized the political transformation in Provisional republicanism's strategy. In terms of typology, rituals such as graveside orations on important commemorative dates, were reimagined to signify not military strength, but political and cultural development, with street theatre taking the place of parading and drilling. However, the peace agreement did not deliver the reunification of Ireland and the end of British rule, which had been the central aims of republican resistance. Dissident groups, who split from the Provisionals as a result of opposition to the Peace Process, have grown in support. Militant groups like the Real IRA (RIRA) have contested the internal cultural hegemony of Sinn Féin by emphasizing paramilitarist traditions at their own commemorations and funerals. By utilizing masked volunteers to deliver graveside orations and employing armed guards to fire gunshots over the coffins of dead members, they have sought to reclaim the ideologically potent performative rituals of the recent past to establish their claims to being the true keepers of republicanism's ideological soul.
\end{abstract}

\section{Keywords}


Commemorative rituals, dissidents, Irish republicanism, Peace Process, Real IRA, Sinn Fein

\section{About the Author}

Paddy Hoey is a lecturer in Media at Edge Hill University. He is completing a PhD at the University of Liverpool's Institute of Irish Studies in the development of Irish republican media strategies since the Good Friday Agreement. With Dr. Niall Carson, he is the co-author of "The Bell and The Blanket: Journals of Irish Republican Dissent" for New Hibernia Review (2012), and with Dr. Robert Busby, he is the co-author of "Éirígí: Changing Narratives in Irish Republican Activism," for the Cambridge Scholars volume Changes in Contemporary Ireland (2013). 


\section{Republican memorialization and republican politics}

In contemporary Irish republicanism there has become apparent an internal battle for the control of the symbols and performative rituals of commemoration linked to the structural reconfiguration of the aims and objectives of the parties and groups within its ideological parameters. The schism is between the dominant ideological political party Sinn Féin, which has gradually assumed the role of Establishment republicanism (McKearney, 2011), and those dissident groups who have diverged from its reformist direction.

Sinn Féin completed a transformation from being the marginalized and subordinate political wing of the Provisional Irish Republican Army (PIRA), to being the dominant nationalist party in Northern Irish nationalism in the 20 years in which it was involved in the Peace Process (Bean, 2007; Maillot, 2005). Although PIRA had waged a 30-year armed campaign of violence against British rule in Northern Ireland, aimed at the unification of Ireland and the ending of British rule in Northern Ireland, Sinn Fein's transformation was not born of a victorious guerilla campaign of liberation, but from being a key actor involved in the Peace Process and the facilitation of the decommissioning of PIRA weapons. During the PIRA campaign, the trappings of militarism including uniformed and armed color parties were central symbolic and aesthetic anchors of Provisional republican culture. However, the 1998 Good Friday Agreement led to the establishment of the devolved Northern Ireland assembly that fell some way short of republicanism's aims of Irish separatism. One of the key internal struggles for Establishment republicanism has been to reconcile the transition from strategies predicated on militarism to reconfiguring them within a peace settlement that has delivered less than republicanism's ultimate goal of a united Ireland.

While Sinn Féin had been engaged in a sustained 30-year strategy of grass-roots activism to build its political and social power and transform the party's raison d'être from political wing to political party, the failure to deliver republicanism's separatist ideals was the root of the emergence of militant dissident groups. While Sinn Féin reimagined the aesthetics and language of commemorative republican tradition to emphasize a new demilitarized movement, dissidents and militants have sought to reclaim and perform older traditions of resistance and defiance.

Sinn Féin's reformist impulses have developed modes of performing republicanism's past that emphasize non military cultural heritage, while the militants have sought to establish their traditional separatist credentials by reaffirming the militarist underpinning of the past. Sinn Féin's new commemorative rituals have stripped Republican memorialization of overt paramilitary trappings. Similar cultural re-imaginings have taken place in wider Northern Irish society in the post GFA era, most prominently with divisive Orange Order 12th of July parades being rebranded as Orange Fest, an inclusive cultural festival rather than a "quasifanatical Protestant," celebration of celebration and otherness (Culture Northern 
Ireland, 2010). Within republicanism, historical reenactment and street theatre have recreated periods of the revolutionary eras, without the defiant, militarist symbolism of the recent past. This "mirrors the changes within the political aspirations of Sinn Féin" and the political and media demands of the normalization process inherent to many post-conflict situations (McDowell 736).

The reemergence of violent and organized dissident groups, such as the armed militants of the Real IRA (RIRA) and Continuity IRA (CIRA) and their associated political outlets, the 32 County Sovereignty Movement (32CSM) and Republican Sinn Féin (RSF), has been based on opposition to the Good Friday Agreement and its confirmation of the partition of Ireland. Within the ambit of the rituals of commemoration, this opposition, based in republican traditionalism, has seen a rejection of Sinn Féin's shift to cultural reenactments of the republican past and a reaffirmation of a performance of republican commemorative rituals that emphasizes militarism and armed force at memorial events. That dissidents have sought to reclaim the tradition of republican militarism at commemorations is emblematic of the ongoing battle for hegemony within republicanism, with the control of the dominant internal and external symbols and narratives central to any conflict (Gramsci 12). Both approaches to commemoration are essentially performative; they are highly choreographed and staged at strategically important physical and psychological occasions for republicans, like gravesides or symbolically important dates in its calendar. Their mise-en-scène is designed to amplify the resonance of the occasions to the audience. Commemorations of military struggle, denuded of militarism in Establishment re-imagination, have become militarized again. The use of masked volunteers at graveside orations, the defiant narratives of their speeches and the performance of military strength are conceived not only to appeal to their own dissident audience, but to convey deeper sense of intent to wider publics via the watching mass media. The mass media has become central in the communication of political strategy in late modernity, and performance, conceived to communicate aims and objectives to wider audiences, has become more important than policy. In effect, politics has become affected by public relations and McNair argues that "the application of the various techniques associated with public relations undermines the communicative and discursive standards required of a healthy democracy" (325). The Northern Irish Peace Process has been a key instance of the shift from the process of political policy to the process of performing politics. The media space became the key battleground of communication, rather than the policy or social space. The dominant political actors within the Peace Process have used the mediated and mediatized space of political communication to convey implicit and explicit meaning to multiple competing publics, both sympathetic and antagonistic to their cause. As Kershaw situated culture within political performance as being "saturated with discourses of power," the exercise of republican rituals can be seen as "fundamentally about the politics of performance" (Kershaw 6). In this sense, the performative rituals of 
Irish republicanism, aimed at conveying progressive demilitarized Establishment messages, or traditional resistance of the militants, is based on both semiotic and verbal nuance. In doing so, it reflects the centrality of both the media as a dominant site of political engagement in the Peace Process (Dixon, 2002) and the highly scripted nature of political communication within in it (Dixon, 2006). It was also an extension of the media as a site of ideological conflict in recent Irish history. The recent coalescence of republicans and the governmental actors in a more benign and mutually supportive space was a key shift from the period of broadcasting bans in the Republic of Ireland (1971-1993) and in the United Kingdom (1988-1994).

\section{Mediation and mediatization in the choreography of the Peace Process}

Commemorative events and their performative rituals are important organizing fulcrums of the republican calendar and have, until the relatively recent past, been the central means of celebrating the sacrifice of the heroes of the republican struggle while also providing a forum in which to restate collective confidence and identity and emphasize optimism for the future success of the republican cause (Jarman 151). They are central points of focus for the republican activist media, framing the production of activist texts and providing a strategic focus for activists themselves (Dalton, 2011). They are however conceived as events that are to be consumed in both a mediated and mediatized sense within the parameters of modern systems of political communication and their meanings are not limited to their immediate publics but operate within established economies of mediation of the macropolitical arena. While mediated communication relates to the role of the mass media in the production and reception of interpersonal communication (Krotz, 2004), it is also a mediating or intermediary force in the interrogation of politics by mass publics (Mazzoleni \& Schultz, 1999). Politics is mediated "whenever the mass media are the main channels through which politics is communicated" (Strömbäck 230), and within the context of the Northern Irish media sphere, the print and broadcast media have had an enormous influence on the communication of politics and, in particular, the promotion of the ideological values of the peace process (Wolfsfeld, 2011; Baker \& McLaughlin, 2010). ${ }^{1}$ As an extension of the influence of the mediated world, staged political events designed for specific mediatized purposes are delineated as "pseudo events" (Boorstin, 1992), specifically designed to fit in with the media agenda and influence it. Republican groups have tended to use commemorations in the manner in which Boorstin theorized press conferences and photo-opportunities, as events and spaces in which to control the framing of information, both in terms of visual and textual interpretation. In this sense, political communication and its performance, have become facets of the mediatized world, where political policy, strategy and presentation are shaped to appeal to "media logic" (Hjarvard, 2008). The media has become, "integrated into the operations 
of social institutions and become institutions themselves," and social interaction "within the respective institutions, between institutions, and in society at large takes place via the media" (Hjarvard 113). The media and its own institutionally processed logic is the dominant arbiter of political and social interaction within the modern mediated space and, as such, public displays by political actors, to gain wider distribution, must satisfy this logic.

Thus, in the case of the conception of the demonstration or performance of politics at political events by political parties, like commemorations, the script, staging and setting are intended to attract the attention of, and influence, media gatekeeping institutions covering them. Form and setting therefore dominate content, aimed at appealing to a media that is involved in the construction of its own internally processed meaning of events and personalities that they report (Altheide \& Snow, 1988).

The specifically mediated / mediatized nature of the Northern Irish Peace Process is another important factor to consider in any analysis of the re-imagining of commemoration by reformist republicans or traditionalist militants. The Peace Process, throughout the period before the signing of the Good Friday Agreement, represented a phase of the propaganda war (Dixon, 2002), which had first been waged against republicans during the Troubles (Curtis, 1998). This phase saw political choreography utilized by "political elites to communicate appropriate messages to various audiences in an attempt to bring them to an accommodation" (Dixon 727). These elites, ranging from the British and Irish governments to local nationalist parties, including Sinn Féin, "coordinated moves to send appropriate messages to conflicting audiences and so push the peace process forward" (Dixon 727). While there remains diverse opinion concerning the ethics and efficacy of the political manipulation or lying inherent to the Peace Process, it provided Sinn Féin with the experience to learn the means through which to communicate effectively its policy and changes of position (Spencer, 2006). Sinn Féin's external framing emphasized demilitarization, normalization, accommodation and progress away from militarism (Bean, 2007), while internally, its rituals also had to balance the conjoined need to celebrate the heritage and sacrifice of the armed struggle from which it had gradually built its political platform. Clearly, this presented ideological problems for traditional republicans for whom the Peace Process delivered less than the sum of their aspirations. The normalization of commemorative rituals symbolized the acceptance of the defeat of republican insurrection and denuded their political identity of the symbolic defiance upon which it had historically been predicated. The stripping of republican commemorations of overt trappings of militarism is not a recent phenomenon and is indicative of a longer held strategy by Sinn Féin. A concerned contributor to the internal provisional republican magazine Iris Bheag (Small Magazine) had noted the changes in the performance of republican commemoration in 1987, observing that the usually armed and masked 
color party had been diminished at a key event, saying "defiance was always one of our strong points, without it we will be left to the history books" (Moloney 302).

\section{The development of republican commemoration}

There are five major events in republican history that are celebrated each year Bloody Sunday (January), the Easter Rising (March/ April), the birth of 1798 leader Wolfe Tone (June), the Hunger Strikes (August), Internment (August), (Jarman, 1997). The rituals evident at these marches and commemorations have been influenced by the culture of republican funerals during the Troubles, and by the older ecclesiastical calendar and religious culture of commemoration of sacrifice, particularly that of Easter. Commemorations for the first three saw an escalation in the use of overt trappings of militarism throughout the 1970s, with uniformed, masked and often armed color parties evident at graveyards where the memorial service were held. While these emphasized strength to the outside world, as mediated events in the current age, they are designed to convey more nuanced expression of republicanism. These mediated events are received and interpreted in the manner of primary, secondary and tertiary media texts (Fiske, 2010), where the tertiary audience also molds the text through interpretative interaction in mediated spaces. The "primary audience," the participants, and those present at commemorations, are implicated in informing the "secondary audience" that receives images and messages via mass media, while the "tertiary" or "subsequent audience," who are informed of the commemoration through mediated representations from the primary and secondary audience, become active interpreters of what has been viewed. The subsequent audience is a vital target for republicanism, in particular Establishment republicanism keen to emphasize its social and political progression away from armed struggle and paramilitarism. This position was communicated in both direct and sub-textual means and commemorative culture was, "a means of rallying the faithful and presenting an image to the world," and had "a number of social functions and multiple meanings for participants and observers" (Bean 126).

Benedict Anderson's analysis of the construct of the imagined community (Anderson, 1996) is important to consider when explicating the performance of republican commemorative rituals. These commonly held and collectively observed, quasi-religious rituals, create physical and psychological spaces within which the republican community forges and develops a collectivized sense of identity that has often been suppressed by the apparatus of the state. They represent the creation of an alternative or surrogate state, in which these performative rituals contribute to the generation of an individualized internal ideological apparatus that sustains it. Republicanism in this sense works as a state within a state (Bean, 2007) and the semireligious nature of the spectacle and observance, and of republican memorialization, inwardly legitimates its subaltern status. That these commemorations and their performative rituals have maintained a central space in the calendars both of 
Establishment and dissident republican groups speaks to the culturally important nature of commemoration in the constitution of Irish Catholic identity. These differ from the celebrations of unionists as commemoration not of successes, but rather the defiant defeats of previous generations which serve as ideological sustenance. These commemorations often remember "history from the point of view of the losers, the victims, each new hurt ratcheting up the memory of the preceding one, and you are not allowed to forget them" (Elliott 11), while republican parades commemorate the continued resolve in defeat and the determination to carry on the fight (Jarman 152). This is an important intergroup ideological dynamic for republicans as, "war commemoration and memorialization is a powerful connecting strand between national allegiance and national identity, and the legitimation of force" (Brown, Viggiani, 2012). These commemorations, even those for failed rebels, have served to construct collectivized modes of belonging among geographically, politically diverse and marginalized people. The commemoration of the symbolic sacrifices of republicans across the last three centuries is intentionally constructive as a unifying force for republican communities still divided by partition.

Ideologically and politically marginalized from the states in which they existed through the twentieth century, the focus of much republican activism on the dead and their sacrifice has allowed for the construction of the imagined collectivized republican "people" in the face of state "repression." These commemorative rituals became particularly important for the republican movement in the 1970s and 1980 where, through the years of state proscription, broadcasting bans and political marginalization, there were few opportunities for overt public displays of political and military strength. During the turbulent period of the Hunger Strikes, color parties firing shots over coffins of dead republican volunteers proved to be a potent symbol of defiance against the British state and were effective propaganda tools for marginalized paramilitary groups, as were the mass mobilizations of republicans for the funerals of the dead men (Mulcahy, 1997). These rituals were both powerful counter hegemonic rituals of defiance against the British presence in Ireland.

Provisional performance is an amalgam, peppered with emotional content and appeals, binding together ritual display, blunt symbolic communication, and public projection of political messages and historic tropes and narratives (Brown Viggiani 225)

In a performative sense, especially taken from the standpoint of reading the propaganda war as a mediatized conflict, the Hunger Strikes marked a success for the Provisional movement. The images of dead hunger strikers, beret and gloves on the open casket at their wakes, the Irish Tricolour draped on their coffins and volleys of shots fired at gravesides, were internal and external shows of defiance captured by the global media. Crucially, they also contributed to a period of momentary mass support for the republican struggle from the Catholic community, 
both north and south of the Irish border, which had previously been opposed to Provisional IRA campaign. The last time there had been mass popular support for the northern nationalist cause in the Republic of Ireland had occurred in 1972 in the aftermath of Bloody Sunday and centered on mass protests which culminated in the burning of British Embassy in Dublin. The mise-en-scène of the republican funeral is important in this instance because it denotes both the sacrifice and the brutality visited upon the dead men and the ultimately symbolically performative nature of their struggle. McLoone notes, "it was important for republicans that these funerals reflected the military nature of their struggle" (211). The resonance of the funeral rites of republican "martyrs" remain powerful symbolic presences within the establishment republican identity, note the centrality of Hunger Striker Bobby Sands to the modern republican folk memory. ${ }^{2}$ The outward militarism of the 1981 funerals and their ritual legacy gradually disappeared from the Provisional activist commemorative repertoire from 1987, initially under pressure from Catholic church leaders (Moloney, 2003). While militarized displays would garner infrequent or isolated focus in the mainstream media in the period of gradual demilitarization, that is from 1987 to the signing of the 1998 agreement, the militants would introduce both masked color parties and volleys of shots in recent years, courting controversy in the process.

As a typology, republican commemorative rituals therefore encompass both commemorations on key dates for the republican struggle and speeches given at the graves of historically and ideologically important figures, usually martyrs for the cause. The graveside or graveyard oration is an enduring feature of republican commemoration, and in its current phase is directly linked to the 1915 oration of Patrick Pearse at the grave of the Fenian leader O'Donovan Rossa. ${ }^{3}$ Graveside orations have been laden with direct and symbolic content and have provided a space to invigorate republicans during periods of struggle and marginalization. They have signposted the changing tenor of Establishment republican thinking while also remaining opportunities for politically marginalized traditionalist republicans to communicate to wider political audiences via the mainstream and activist media.

Prior to the Peace Process and at the outset of the Provisionals "Long War" strategy aimed at forcing British public opinion to call for a withdrawal of troops (O'Brien, 1999), Jimmy Drumm's speech at the symbolically important Bodenstown ${ }^{4}$ cemetery signposted a shift in Provisional republican thinking with a more pronounced left wing perspective emerging (Bean \& Hayes, 2009). For Sinn Féin, Bodenstown has become an important site to communicate the gradualist move away from militarism, while still situating these reforms in the important ideological legacy of Wolfe Tone for the wider republican movement. Key addresses at Bodenstown commemorations would signify reforms in the establishment republican movement, with one in particular, by Sinn Féin's Jim Gibney in 1992, "preparing the 'base' for a dramatic shift in position" (Bean 185). The response of 
militants in the recent years of increased dissident activity, was to use their own commemorative graveyard orations to reclaim for traditionalist performative purposes, with masked volunteers reading defiant messages, including threatening a campaign of attacks in Britain (Bates, 2009a).

\section{Performance, power and media reaction to recent republican commemorative rituals}

While dissident republicans were involved in a recapturing of the defiant aesthetics and performance of older commemorative rituals, Sinn Féin was involved in its own development of the commemorative repertoire. The new means of republican commemoration would see a marked difference in the dress and manner of those parading and would also incorporate street-theatre and reenactment of the republican struggle. These were operational examples of the changing aesthetic and narrative linked to Sinn Féin's demilitarization of the IRA and its reconfigured role within the republican movement. The Irish News noted of the 2005 Bodenstown commemoration:

The event has been traditionally led by a colour party wearing black berets and black or khaki jumpers. But this year was different. Gone were the paramilitary trappings and in their place a colour party wore green blazers. It could have been a parade led by tennis umpires at Wimbledon. (Murphy, 2005)

The process was part of the modern political makeover that "re-branded the IRA," both for internal and external audiences (Murphy, 2005). However, the changing nature of establishment republican commemoration was more than simply an aesthetic re-branding exercise in a modern corporate sense, but was central to the shift from armed political struggle to one which situated the struggle within the wider context of identity politics that emphasized Irish language, history and culture as shared cultural values for nationalists beyond the republican hinterland (Bean, 2005). To re-iterate McDowell, this reflected the changing political ambitions of Sinn Féin, now the leading nationalist party in government in the north, that had significantly increased its vote and profile in the Republic of Ireland. ${ }^{5}$

The re-branding process also encapsulated the new repertoire of performance that replaced displays of militarism and strength with street theatre and tableaux which recreated republicanism's past for the internal audience, but which was stripped of "menace" for those outside of republicanism. This strategy was initially utilized in Bloody Sunday remembrance marches in Derry in the late 1990s, where street theatre, aimed at parodying the original discredited Widgery Report into the events of the 1972 atrocity, became a "playful, carnivalesque and symbolic inversion of the canonical official memory" (Conway 116). ${ }^{6}$ This use of 
drama and reenactment has developed to include performative interpretations of republicanism's past, including representations of the 1916 Easter Rising and the Hunger Strikes (Ógra Shinn Féin, 2010). In 2010, 2011 and 2013, the Easter Rising was marked in County Tyrone's annual commemoration by street-theatre productions of specific events of the rebellion. Prior to the 2010 reenactment, Sinn Féin councilor Sean Begley stated, "A reenactment of this historic event would not only provide good theatre, but would be extremely educational, as well as being a fitting way to remember those who have died" (West Tyrone Sinn Féin, 2010). Rather than being designed for a politically heuristic, emotional response of solidarity and defiance, it was aimed at different emotional modality. It was reported after the event that "the reenactment was very poignant and emotional, particularly the execution scenes, and received a rapturous round of applause from the hundreds who turned out to watch" (Ógra Shinn Féin, 2010). Photographic evidence of the performance shows costumed volunteers recreating the early actions of the uprising and being executed before an audience on the streets of Carrickmore, a predominantly nationalist town in County Tyrone. (Ógra Shinn Féin, 2010). Building on this "Sealed Knot" style recreation spectacle of 2010, the 2013 Easter commemoration utilized a dramatic script and narrative and portrayed the story of 1916 leader Joseph Plunkett and Grace Gifford, the woman he married hours before his execution by the British government. Written and choreographed by a local author, it was also performed by actors in a conventional piece of theatre (West Tyrone Sinn Féin, 2013). It marked a new dimension in the breadth and scope of commemoration in the modern establishment republican movement.

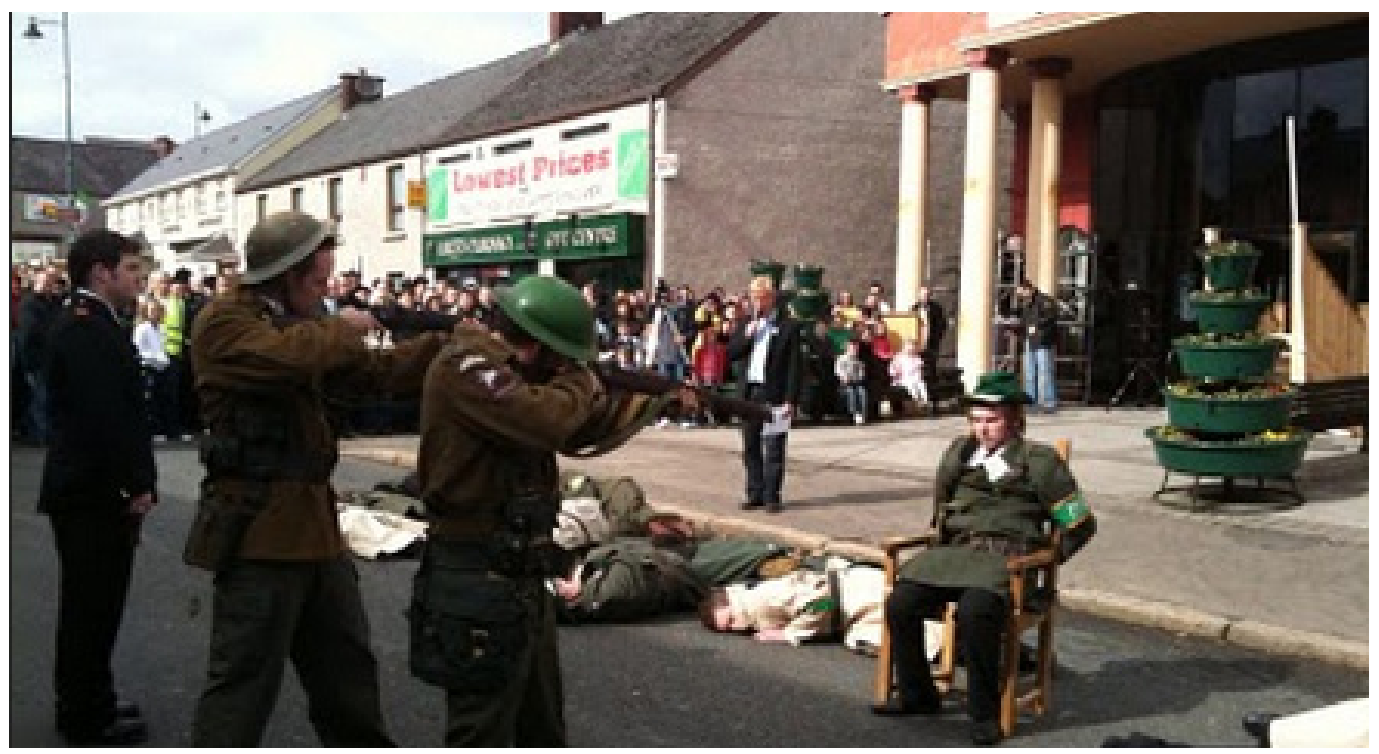

Fig. 1: 1916 Re-enactment: Sinn Féin activists recreate the executions of 1916 Easter Rising leaders 
While these commemorations were divested of the "threat" of older displays of defiance, some have remained controversial within the context of the contested space of commemorative culture of Northern Ireland. In August 2009, at an annual Sinn Féin Hunger Strike commemoration in the County Tyrone town of Galbally, men "paraded" as IRA volunteers on patrol, armed with replica weapons, before a series of tableaux were performed demonstrating various phases in the life and death of a hunger striker, from arrest, to interrogation and the deathbed scene. These performances included activists and volunteers playing parts of IRA men, British soldiers, police interrogators and family and clergy. However, despite being divested of the overt menace or defiance of the revolutionary era, they caused controversy after being displayed on blogs and the social media photography website Flickr. com (Fealty, 2009). This controversy was illustrative of a deeper power battle lying at the centre of the Peace Process away from the ideological inter group disputes of republicanism. Firstly, the use of replica weapons on a local sporting ground owned by the Gaelic Athletic Association, a predominantly nationalist organization, were the focus of objections by pro-British unionist politicians and newspapers with a unionist political standpoint. Nelson McCausland, the Northern Ireland sports minister from the hardline Democratic Unionist Party, told the unionist newspaper The Newsletter,

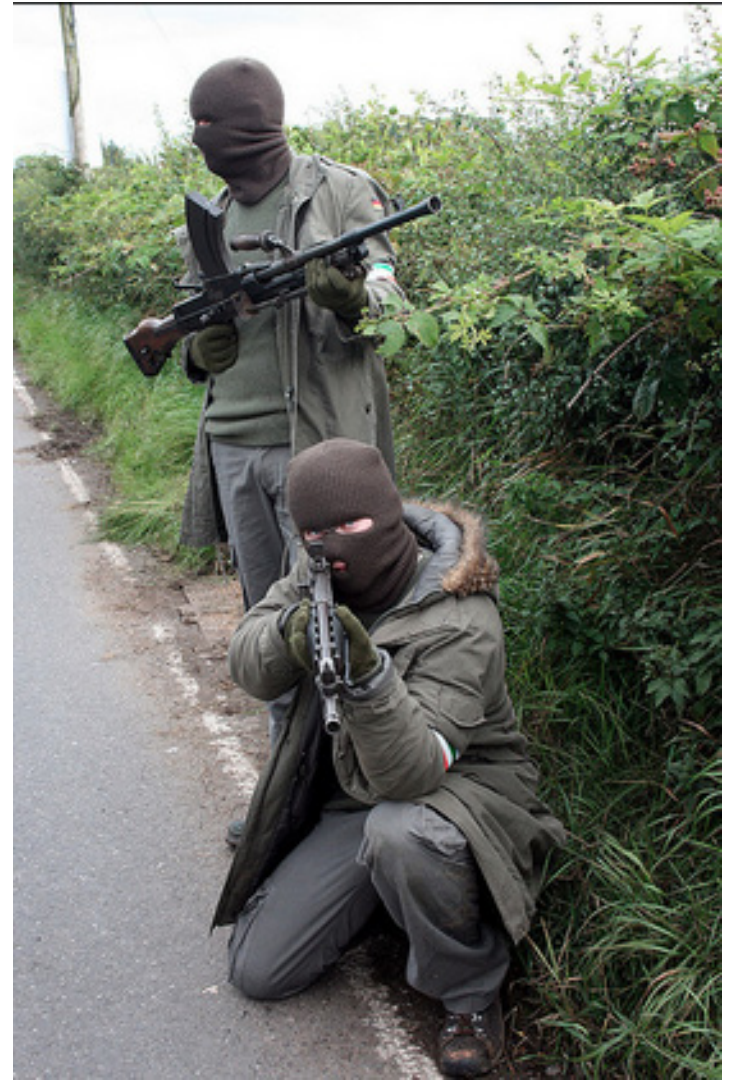

Sport has tremendous potential to bring communities together and to contribute to a shared and better future. This is an aspiration to which the vast majority of the population here subscribe. The events in Galbally have been deeply divisive and do nothing to promote harmony in our community. (Purdy, 2009)

Secondly, the ethno-religious fault lines inherent in performing both the Peace Process and performing the past were evident within the context of the direct contemporary political context of the Galbally reenactment. While the republican movement has remained committed

Fig. 2: Active service: A re-enactment of IRA active service at a Hunger Strikes commemoration 
and "proud of the contribution made by IRA volunteers... just like unionists have every right to honour their dead," (Maguire, 2012), it did so within the symbolically contested space of commemorative politics in Northern Ireland. As Sinn Féin was involved in historical street theatre at Galbally, it was also actively campaigning for the banning of Unionist Orange commemorative parades held in Catholic areas. In this case, it objected to the display of paramilitary flags at Orange marches. In the aftermath of one petition against a march, in Co Antrim, there were tit-for-tat reprisals of vandalism on an Orange Hall and an Ancient Order of Hibernians Hall (Newsletter, 2009). ${ }^{7}$ Despite the changing nature of the performance of republican self-memorialization as an outward symbol of progress away from militarism, the interpretative symbols of commemoration remained contested and divisive within the overarching power struggle of the Peace Process and Sinn Féin was charged with holding double standards (Henry, 2009). However, it must be noted that after the conflict over the Galbally reenactment and a further storm surrounding the use of replica weapons in a Hunger Strike memorial in Dungiven, in August 2012, Sinn Féin, "called for an end to military paraphernalia at nationalist parades" (Belfast Telegraph, 2012). The advent of online and social media expanded the canon of activist media strategies, and enabled activists to exercise a greater degree of narrative control. In an interesting intervention on a news blog, senior Sinn Féin figure Sean Murray, responded to an online news article on the Dungiven commemoration, with the words,

We need to question the display of replica weapons as a form of pageantry at some Hunger Strike commemorations. What message does this send out in the context of a genuine drive for reconciliation and nation building? Do some of our bands in military style uniform, with militarist symbols on drums convey a sense of de-militarization and an acceptance of peaceful and democratic means? These and other questions are already being debated within Republican circles. (Rowan, 2012)

\section{Dissident republicanism: reclaiming paramilitary symbolism}

While Sinn Féin was in the process of developing a new form of expressive republican commemorative reenactment, dissident republicans were involved in recapturing the symbolic rituals of the revolutionary era. Two months after the Galbally commemoration, Real IRA volunteer John Brady died in police custody in Derry (McDonald, 2009a). At his funeral, the trappings of Hunger Strike-era funerals returned, and would set a pattern for both the commemorative rituals of dissidents and their reporting by the mainstream media. The dead man's body was photographed for dissident media outlets in open casket, his gloves and beret displayed prominently as it was saluted by a four man masked guard (Republican 
News, 2009). Prior to his funeral service, the volley of shots fired over the coffin, that evoked the rituals of the Hunger Strike era was described by the Guardian newspaper as a "show of strength" (McDonald, 2009b), and as a "chilling scene that should have been consigned to history," by the right wing Daily Mail (Bates, 2009b). Coming towards the end of a year when dissident republicanism was resurgent after the killings of three members of the security forces and 22 armed attacks in total, it was a show of strength designed to send out a message of defiance to the British and Irish governments, Sinn Féin, and the political community as a whole. As a performance, it was designed to highlight that dissidents, in this case the Real IRA, were the real keepers of the republican flame and its performative rituals of commemoration mandated their guardianship of militant republicanism's contemporary legitimacy. It was the latest example of republican groups making apparent Gerry Adams' famous phrase about the IRA prior to decommissioning, "they haven't gone away, you know," described by novelist Glenn Patterson as "one of the soundbites of the Post Troubles era." (Patterson, 2011)

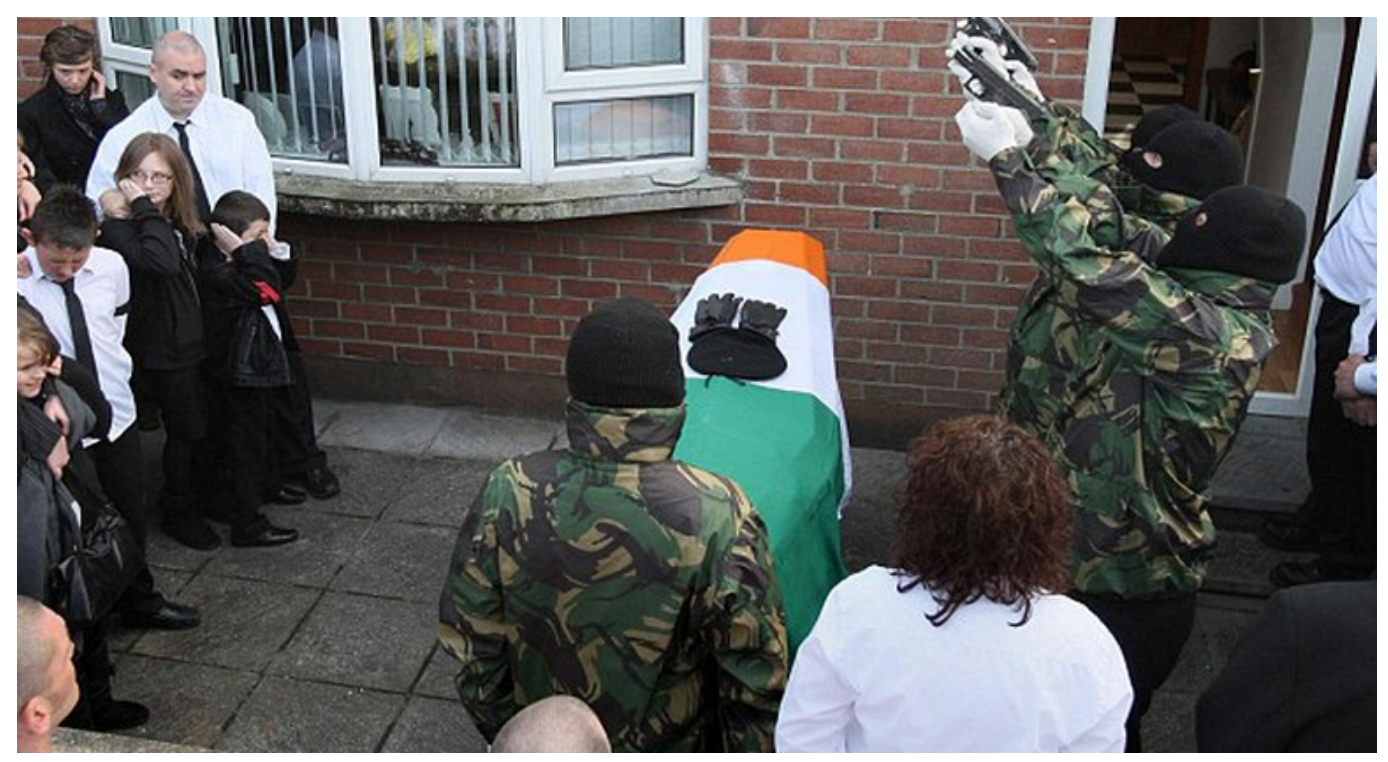

Fig. 3: Brady Funeral: The armed salute over the coffin of John Brady

This sense of recapturing and restating the custodianship of traditional commemorative rituals for wider mediatized purpose was evident in 2012, when the Real IRA used the funeral of Dublin volunteer Alan Ryan to stage a similar funeral. However, that it took place in the Republic of Ireland, where support for republican militants was more diminished than in Northern Ireland, and isolated to small pockets of geographically specific support, is central to its defiant design. It was also criticized due to links between dissident activity and conventional 
forms of criminality in the Republic of Ireland. While in Northern Ireland, the Peace Process's legitimation of diverse political activist groups has accommodated dissidents to some extent, in the Republic of Ireland, they were largely portrayed as conventional criminal gangs. The color party and volley of shots at the Ryan funeral were a more menacing echo of the republican past, as were other symbols of republican commemoration, like black flags hung on lamp posts close to Ryan's North Dublin home.

The arbitrative role of the media is central to the interpretation of dissident commemoration in this instance. While the British and Northern Ireland-based media had been more circumspect in their denunciation of the spectacle at Brady's funeral, sectors of the traditionally anti-republican media in the Republic of Ireland were more forceful in their condemnation of the Real IRA, and its "well-choreographed republican funeral" (Irish Independent, 2012). Using an interpretation of the past that Establishment republicanism had been keen to avoid comparisons with, the Irish Independent noted of the Real IRA,

They would turn Alan Ryan, extortionist and killer, into a martyr who died fighting the drug barons on behalf of the downtrodden working classes. The RIRA had its equivalent of Bobby Sands." (Irish Independent, 2012)

However, despite reclaiming the traditional means of performing the republican past, the dissidents achieved little political or media capital with the display, which could, at best, be read as merely indulging in paramilitary nostalgia for a limited number of core supporters. Mícheál Mac Donncha, Sinn Féin's councillor for the area, and former editor of the party newspaper, An Phoblacht (The Republic), said (in quotes widely circulated by the mainstream media), "this violent faction is rejected by the community in Donaghmede and that they represent no-one but themselves" (Sinn Féin, 2012). The justice minister in the republic, Alan Shatter, equated the spectacle as atavistic, serving as a performance of a primal and base nature,

Paramilitary trappings should not blind people to the fact that what is at issue is criminal terrorism carried on by people who, for their own reasons, want to drag the people of this island back to a dark past." (Lally, 2012)

The spectacle of masked men delivering graveyard orations at commemorations was also an important element which returned to the traditional militant repertoire, or rather, received increased coverage in the media. Unionist politicians and the mainstream media condemned Real IRA orations at Easter 2009 and 2012 commemorations. A 2009 Easter commemoration speech which threatened violence in Britain, just weeks after dissident murders of the two soldiers and a policeman in two separate incidents, received increased coverage from major news 
organizations. In both instances the militarized display of defiance and the 'oration' were amplified by the media as implicitly threatening spectacles despite not overtly being designated as such by the security forces. This internal logic of media organizations clearly saw dissident performances as inherently more newsworthy because of their links to dissident violence. The 2012 oration, which utilized much of the language of traditional republican resistance of the Troubles and declared that the Real IRA would continue to target "crown forces" and "British interests and infrastructure," was a target for Unionist politicians, who called for "a more serious approach" to policing commemorations and dissident shows of strength (McDonald, 2012). As the dissident threat had become elevated after a number of attacks and murders on the security forces and increased instances of localized rioting in areas that had passed into dissident control, mediatized responses had called for a clampdown on any shows of strength, including those at commemorations. Certainly, in the Easter commemorations of 2013, dissident commemorations were muted and were denuded of overt trappings of paramilitarism.

\section{Conclusion}

Republican commemorative culture is inherently performative, and works on a number of important levels that reflect the wider narratives of the political situation in which it finds itself and the narrower ideological issues surrounding the situation of contemporary republicanism itself. The performance of republicanism's past in dramatic tableaux or street theatre perhaps reflects the effects of the widening historical and ideological distance between the revolutionary periods surrounding the 1916 Rising and the 1980/81 Hunger Strikes and the growing, younger voter base of Sinn Féin. It also reflects the changing nature of the Sinn Féin which is embedded in parliaments in Northern Ireland and the Republic of Ireland. As a result, its public expressions are consistently configured to appeal to either the mainstream media, or, at least, not to invite its criticism. Sinn Féin speaks more broadly, beyond the confines of the older radical sector of republicanism in which are situated the traditionalists and militants. For Sinn Féin the struggle has moved beyond that of revolutionary liberation movement, and its performances of the past represent the struggle of cultural and identity politics at the heart of the Peace Process. The counter hegemonic struggle is situated in the reconfiguration of commemorative rituals that contribute to the legitimation of Establishment republicanism culturally and politically it is a performance of the process of peace. The dissidents, on the other hand, represent a continuation of traditional republicanism, at least in terms of their commemorative rituals. It is necessary to note in closing, that the dissidents are merely a section of those republicans that have taken anti-Good Friday Agreement positions. However, dissident commemorations that use the setting, language and rituals of the revolutionary era, remain performances. They are means of signifying their standpoint and exaggerating their strength, primarily designed as internal 
displays for activists and supporters, but with episodes of mainstream media attention. Their performance of the past is a means of establishing their credentials as republicanism's custodians in the present, perhaps quixotically in the face of the overwhelming social and political influence of Sinn Féin. 


\section{Notes}

1. Baker \& McLaughlin suggest that the media was an active and emotionally involved agent in the dissemination of the "Propaganda of Peace" which emerged across a range of media and cultural texts after the signing of the Good Friday Agreement in 1998.

2. The Bobby Sands Trust, set up in the memory of the 1981 Hunger Striker, works effectively as the executor of his cultural legacy. It holds the copyright to publish his poetry and prose and acts to, "inspire Irish republicans in their pursuit of freedom from British rule." The battle over the control of the republican commemorative rituals and folk memory is highly evident with the Trust. It is administered by a board including several senior Sinn Féin members, but was denounced by Sands' family as "acting as an extension of SF (Sinn Féin)" (Moloney, 2000).

3. O'Donovan Rossa was a member of the Irish republican separatist organization, the Fenians, and was jailed in England in $\mathbf{1 8 6 5}$ for plotting a Fenian rising. He was a member of the Irish Republican Brotherhood and coordinated the Dynamite Campaign in England of the 1880s. The IRB would go on to be the dominant group in the execution of the 1916 Easter Rising which has remained a huge ideological and cultural influence on republicans. The oration, given at his graveside by Patrick Pearse, which ended with the words, "Ireland unfree shall never be at peace," was a significant ideological sustenance to the Provisionals during the Troubles.

4. The annual Bodenstown commemoration in Sallins graveyard in Co. Kildare celebrates the birth of the 1798 United Irishmen leader and the progenitor of modern republicanism, Theobald Wolfe Tone. It is a hallowed space, both physically and ideologically for republicans, given Tone's non-sectarian Enlightenment republicanism. His quote, "To unite Protestant, Catholic and Dissenter under the common name of Irishmen in order break the connection with England, the never failing source of all our political evils, that was my aim," has become a rallying cry for many republican groups and is included in most orations at his commemoration. In recent years, seven separate republican groups have held annual commemorations at his graveside.

5. Sinn Féin's journey from the political wing of the PIRA to the political mainstream was signposted when it replaced the SDLP as the largest nationalist party in Northern Ireland in 2001. Its vote has grown markedly in the Republic of Ireland and it gained $13 \%$ of the popular vote in the 2011 general election.

6. The recreation of Bloody Sunday also echoes the documentary theatre production Scenes from the Saville Inquiry by Nicholas Kent and the Tricycle Theatre in 2005. Kent told the Guardian newspaper, "The audience can't be as passive as they would normally be. They can't say, 'Sit back and entertain me' They have to listen, they have to bring an inquiring mind." (Hoggard, 2005)

7. The Orange Order is a Protestant group celebrating the victory of the Protestant King of England, William of Orange, at the Battle of the Boyne in 169o. It is a strong political influence among northern Protestants and is central to the 
marching season in Northern Ireland. Its halls have historically been targets for bombings, firebomb attacks and vandalism. The Ancient Order of Hibernians is a Catholic nationalist organisation that had a strong political influence at the turn of the 2oth Century. It is, however, a marginal influence in modern nationalist society, but its drinking clubs are symbols of Catholic mobilization, which is why they are targeted for sectarian acts.

8. The Sealed Knot is the best-known British historical society involved in recreations of the English Civil War, named after a secret 17th Century group who wanted the restoration of the English monarchy.

\section{Works Cited}

Altheide, David L., and Robert P. Snow. "Toward a Theory of Mediation." Communication Yearbook 11. 1988. 194-223. Print.

Anderson, Benedict. Imagined Communities. New York: Verso, 2006. Print.

Baker, Stephen., and Greg McLaughlin. The Propaganda of Peace. Bristol: Intellect, 2010.

Bates, Daniel. "Real IRA Real IRA threatens new attacks on mainland Britain in Easter message of hate." Daily Mail 15 April, 2009. Web.

--.. "Shots fired at IRA man's funeral." Daily Mail, 9 October 2009. Web.

Bean, Kevin. The New Politics of Sinn Féin. Liverpool: Liverpool UP, 2007. Print.

--- and Mark Hayes. "Sinn Féin and the New Republicanism in Ireland: Electoral Progress, Political Stasis, and Ideological Failure." Radical History Review (Spring 2009) 104: 126-142.Print.

Boorstin, Daniel J. The image: A guide to Pseudo-Events in America. New York: Vintage, 1992. Print.

Conway, Brian. "Moving Through Time and Space: Performing Bodies in Derry, Northern Ireland." Journal of Historical Sociology. 20.12 (2007): 102-125. Print.

Curtis, Liz. Ireland: The Propaganda War: the Media and "the Battle for Hearts and Minds." Belfast: Sesta, 1998. Print.

"Belfast's Twelfth Celebrations Get a Radical Overhaul." Culture Northern Ireland. 2 July 2010. Web.

Dalton, Des. President Republican Sinn Féin. Personal Interview. May 2011.

Dixon, Paul, "Political Skills or Lying and Manipulation? The Choreography of the Northern Ireland Peace Process." Political Studies 50:3 (2002): 725-41. Print.

--. "Performing the Northern Ireland Peace Process on the World Stage." Political Science Quarterly 121:1 (2006): 61-91. Print.

Elliott, Marianne. Whenever God Took Sides. Oxford: Oxford UP, 2009. Print.

Graham, Brian, and Yvonne Whelan. "The Legacies of the Dead: Commemorating the Troubles in Northern Ireland." Environment and Planning D 25.3 (2007): 476-495. Print.

Gramsci, A. Selections from the Prison Notebooks. New York: Lawrence \& Wishart Ltd. 1971. Print. 
Henry, Lesley-Anne. "Sinn Féin Accused of Hypocrisy over Loyalist Parade." Newsletter. 21 Aug. 2009. Web.

Hjarvard, Stig. "The Mediatization of Society." Nordicom Review 29.2 (2008): 105-134. Print.

Hoggard, Liz, "Out of Crises, a Drama." The Observer. 27 Mar. 2005. Web.

--. "The Truth about Alan Ryan and His Funeral." Irish Independent.15 Sep. 2012. Web.

Jarman, Neil. Material Conflicts: Parades and Visual Display in Northern Ireland. Oxford: Berg, 1997. Print.

Kershaw, Baz. The Politics of Performance: Radical Theatre as Cultural Intervention. London: Routledge, 2002.

Kilpatrick, Chris. "Ex-IRA Chief Calls for the End to Military-Style Parades." Belfast Telegraph 12 Sept. 2012.

Krotz, Friedrich. "Mediatization: A Concept with which to Grasp Media and Societal Change." Mediatization: Concepts, Changes, Consequences. Ed. Knut Lundby. New York: Peter Lang. 2009. Print.

Lally, Conor. "Shatter Decries Paramilitary Trappings." Irish Times. 1o September 2012. Web.

Maillot, Agnès. New Sinn Féin: Irish Republicanism in the Twenty-First Century.

Abingdon: Routledge, 2005. Print.

McDonald, Henry. "Inquiry begins into death of ex-IRA man in custody." The Guardian. 4. Oct. 2009. Web.

--. "Shots Fired in Salute at Real IRA Man's Funeral." The Guardian. 8 Oct. 2009. Web.

McDowell, Sara. "Armalite, the Ballot Box and Memorialization: Sinn Féin and the State in Post-Conflict Northern Ireland." The Round Table: The Commonwealth Journal of International Affairs 96.3993 (2007): 725-738. Print.

McKearney, Tommy, The Provisional IRA: From Insurrection to Parliament. London: Pluto, 2011. Print.

McLoone, Martin. "Traditions of Representation: Political Violence and the Myth of Atavism." Terrorism, Media, Liberation. Ed. J. David Slocum. Brunswick: Rutgers UP, 2005. 209-231. Print.

McNair, Brian. "PR Must Die: Spin, Anti-Spin and Political Public Relations in the UK, 1997-2004." Journalism Studies 5.3 (2004): 325-338. Print.

Maguire, Anna. "Walk Tribute to IRA Gang Sparks Row." Belfast Telegraph. 11 April, 2012. Web.

Mazzoleni, Gianpietro, and Winfried Schulz. “'Mediatization' of Politics: A Challenge for Democracy?" Political Communication 16.3 (1999): 247-261. Print.

Moloney, Ed. "Sands' Family Considering Legal Action Against The Bobby Sands Trust." Sunday Tribune. 2 July 200o. Web.

Moloney, Ed. Secret History of the IRA. London: Penguin, 2003. Print.

Murphy, Patrick. "IRA Rebranding Makes Transformation Painless." Irish News. 29 June 2005. Web.

Mulcahy, Aogan. "Claims-Making and the Construction of Legitimacy: Press Coverage of the 1981 Northern Irish Hunger Strike." Soc. Probs. 42 (1995): 449. Print.

--. "Sectarian Attacks Ahead of Rasharkin Parade." Newsletter. 17 Aug. 2009. Web.

Kritika Kultura 21/22 (2013/2014): -021

(c) Ateneo de Manila University

<http://kritikakultura.ateneo.net> 
Ógra Shinn Féin. "Tyrone Republican Youth Play Leading Role in County Commemoration." Blogspot.com. 10 Apr. 2010. Web.

Patterson, Glenn, 'The IRA Is a Tradition, Not an Army. It Hasn't Gone Away." The Guardian. 26 Apr. 2011. Web.

Purdy, Martina. "Galbally." The Devenport Diaries. BBC.com. 20 August, 2009. Web.

Rowan, Brian. "Marching Madness and Parading Plays - Brian Rowan on a Poison within the Peace Process." eamonnmallie.com. 6 Sep. 2012. Web.

Sinn Féín. "Violent Faction is Rejected by Community in Donaghmede - Councillor Mícheál Mac Donncha." Sinn Fein News. 9 Sep. 2012.Web.

'Sinn Fein are Leading the Way'. An Phoblacht, 29 April 2011. Web.

Spencer, Graham. "Sinn Féin and the Media in Northern Ireland: the New Terrain of Policy Articulation." Irish Political Studies 21.3 (2006): 355-382. Print.

Strömbäck, Jesper. "Four Phases of Mediatization: An Analysis of the Mediatization of Politics." Press/Politics 13.3 (2008): 228-246. Print.

West Tyrone Sinn Féin. "Story of Grace to be Told in Easter Street Theatre." 26 Mar. 2013. Web.

Wolfsfeld, Gadi, Making Sense of Media and Politics. New York: Routledge, 2011. Print. 